\title{
Pintando e desenhando Pinóquio e Kiriku na Escola
}

Renato Noguera ${ }^{1}$

Cátia Gutman ${ }^{2}$

Dayane Feitosa ${ }^{3}$

Resumo: O objetivo deste artigo é relatar os resultados parciais de uma pesquisa em seu início. Durante os primeiros quatro encontros entre pesquisadoras adultas e pesquisadores adultos com crianças de uma escola privada, o ponto de partida foi a exibição dos filmes: Pinóquio (1940) e Kiriku e a Feiticeira (1998). Isso foi a base para crianças do grupo focal conversarem, escreverem e desenharem a compreensão sobre o significado da infância nos dois filmes.

Palavras-chave: pintando, desenhando, escola.

\section{Painting and drawing Pinocchio and Kirikou at School}

Abstract: The aim of this article is to report the partial results of a research's onset. In the first four meetings of female and male researchers, the starting point was the screening of the movies Pinocchio (1940) and Kirikou and the Sorceress (1998). This was the basis for children in a focus group to talk, write and draw their understanding about the meaning of childhood in both films.

Key-words: painting, drawing, school.

\section{Breve introdução}

Este artigo é o resultado parcial de uma pesquisa iniciada em 2017 numa escola privada localizada numa das maiores cidades da região metropolitana do Estado do Rio de Janeiro. Na época, a equipe era formada por integrantes do Grupo de Pesquisa Afroperspectivas, Saberes e Interseções (Afrosin), uma instância acadêmica devidamente registrada no Diretório de Grupos de Pesquisa do Conselho Nacional de Desenvolvimento Científico e Tecnológico (CNPq), e, sediada na Universidade Federal

\footnotetext{
${ }^{1}$ Renato Noguera é pesquisador e professor da Universidade Federal Rural do Rio de Janeiro (UFRRJ), docente do Departamento de Educação e Sociedade (DES), do Programa de Pós-Graduação em Educação, Contextos Contemporâneos e Demandas Populares (PPGEDuc), do Programa de Pós-Graduação em Filosofia (PPGFil) da UFRRJ. Professor colaborador do Programa de Pós-Graduação Filosofia e Ensino (PPFEN) do Centro Federal de Educação Tecnológica Celso Suckow da Fonseca do Rio de Janeiro(Cefet/RJ). E-mail: renatonoguera@ymail.com

${ }^{2}$ Doutoranda do PPGEDuc da UFRRJ sob orientação de Renato Noguera.

${ }^{3}$ Graduanda em Pedagogia da UFRRJ, bolsista do Programa Institucional de Bolsas de Iniciação Científica (PIBIC) sob orientação de Renato Noguera.
}

\begin{tabular}{|l|l|l|l|l|l|}
\hline APRENDER - Cad. de Filosofia e Psic. da Educação & Vitória da Conquista & Ano XI & n. 18 & p. 75-94 & jul./dez.2017 \\
\hline
\end{tabular}


Rural do Rio de Janeiro (UFRRJ). Afrosin comporta duas linhas de pesquisa: $1^{\text {a)}}$ ) Afroperspectivas filosóficas; $2^{a}$ ) Infâncias, Educação, Artes, Natureza, Relações ÉtnicoRaciais e de Gênero. É no contexto desta segunda que se incluem pesquisas com crianças.

As crianças envolvidas na pesquisa são de uma escola situada especificamente na Baixada Fluminense, uma instituição onde o trabalho com pesquisadores e pesquisadoras de universidades tem sido bem aceito. Nós recebemos o apoio de todo corpo docente e a disponibilidade de dois estagiários. Ela é estruturada em turmas de Educação Infantil, Ensino Fundamental do $1^{\circ}$ ao $9^{\circ}$ anos e Ensino Médio. São 16 salas de aula, pátio coberto, salas de Matemática, Ciências, Química e Física. Uma biblioteca, cujo acervo não foi alvo de nosso escrutínio. Aqui vamos denominar essa instituição privada de Escola do Bairro. A nossa equipe é formada por um docente ${ }^{4}$ e suas orientadas ${ }^{5}$ e um orientando ${ }^{6}$ em níveis de graduação e pós-graduação strictu sensu teve apoio de professoras e estagiários e estagiárias da Escola.

De forma preliminar, a pesquisa pretendia analisar uma hipótese simples partindo da exibição de dois filmes Pinóquio e Kiriku e a feiticeira ${ }^{8}$. As crianças avaliam que na história de Kiriku, a infância tem mais aspectos positivos do que na aventura de Pinóquio? Nosso referencial para esse entendimento está em estudos sobre modelos de infância presentes nos filmes mencionados. Em Pinóquio e Kiriku: infância(s) e educação nas filosofia de Kant e Ramose, e, no texto Kiriku: heterônimo da infância como experiência e da experiência da infância publicado nos Anais do I Congresso de Estudos da Infância realizado de 08 a 10 de Agosto de 2017 na Universidade do Estado do Rio de Janeiro (Uerj). Nos dois trabalhos encontramos formulações que contrastam os conceitos de infância presentes nas duas narrativas. Conforme essas pesquisas, a concepção de infância no filme de Kiriku é antagônica a que emerge da trama de Pinóquio.

A pesquisa de campo teve como objetivo inicial analisar a percepção que as crianças têm dos dois meninos. Se a leitura das crianças dos filmes coincidiria com as formulações feitas nesses estudos mencionados. As crianças perceberiam uma ideia negativa de infância no Pinóquio? E um grau espetacular de autonomia infantil no filme Kiriku? Como primeiro

\footnotetext{
${ }^{4}$ Renato Noguera.

${ }^{5}$ Cátia Gutman (doutoranda PPGEDuc), Susana Targino (mestra em Educação pelo PPGEDuc), Juliana Correa (mestranda em Educação pelo PPGEDuc), Bianca Cristina Trindade (mestranda em Educação pelo PPGEDuc), Luiza Helena Braga (graduanda em História) Dayanne Feitosa (graduanda em Pedagogia).

${ }^{6}$ Rogério Brunelli (mestre em Filosofia e Ensino pelo PPFEN).

${ }^{7}$ Filme estadunidense produzido por Walt Disney, direção de Norman Ferguson e estreia em 1940.

${ }^{8}$ Co-produção envolvendo vários países, tais como Luxemburgo, França e Senegal. Sob direção de Michel Ocelot, lançamento em 1998.
} 
modo de mensurar as avaliações das crianças, propusemos o desenho como a ferramenta para esse diálogo.

Dentre as questões que nos interessam estão as percepções das crianças sobre os protagonistas. O tema geral é o que as crianças pensam sobre a infância? O que Pinóquio tem a dizer sobre a infância? O que Kiriku tem a dizer sobre a infância? Como analisam as perspectivas dos dois personagens a infância? Será que as crianças fariam alguma ligação entre o personagem branco e algum tipo de cultura branca europeia sobre a infância? Do mesmo modo, a percepção do personagem negro seria associada à cultura africana? As crianças comentariam a ausência de personagens infantis femininas protagonistas nas duas histórias? Numa perspectiva mais geral, quais as perspectivas de infância presentes em cada narrativa?

\section{Entrando em campo e algumas perspectivas teóricas}

A Escola do Bairro possui uma sala de aula para cada série, do $1^{\circ}$ ao $5^{\circ}$ Anos temos cinco turmas. Em conversações com a Equipe Pedagógica e a Direção da Escola do Bairro, definimos quatro encontros com crianças previamente selecionadas, estabelecendo como metodologia de pesquisa o grupo focal. Aqui, "grupo focal representa uma técnica de coleta de dados que, a partir da interação grupal, promove uma ampla problematização sobre um tema ou foco específico” (BACKES et all., 2011, p. 438).

Inicialmente, o grupo focal contaria com quatro crianças por ano escolar, sendo duas meninas (uma negra - preta ou parda - e uma branca) e dois meninos (um negro preto ou pardo - e um branco), totalizando 20 crianças dos anos iniciais. A pedagoga sugeriu a inclusão de crianças com deficiência e altas habilidades, o que aumentou o número de participantes para 25 crianças no total. O critério para seleção das crianças foi definido com as professoras do $3^{\circ}$ e $4^{\circ}$ anos. Após conversas, elas definiram que o critério de escolha seria por crianças que participavam mais ativamente das aulas e contavam com boa redação, além de terem interesse em participar. A justificativa para essa repartição em que a quantidade de crianças negras e brancas, assim como de meninas e meninos fosse a mesma se ancora na orientação da linha de pesquisa do Afrosin: "Infâncias, Educação, Artes, Natureza, Relações Étnico-Raciais e de Gênero". A nossa agenda de investigação se interessa pelas diferenças de percepção, intervenção entre crianças negras, indígenas e brancas, entre meninas e meninos, assim como nas interseções entre gênero, raça e etnia. Daí, considerando que no contexto da Escola do Bairro só tínhamos autodeclarações e 
heterodeclarações que apontaram a existência de crianças negras (pretas e pardas) e brancas mantivemos nosso foco nessa relação. ${ }^{9}$

Antes da seleção do grupo focal ser concluída, todas as crianças assistiram aos filmes Pinóquio ${ }^{10}$ e Kiriku e a feiticeira ${ }^{11}$. As conversas iniciaram a partir dos dois filmes. Por quatro dias, 30 de novembro e 05, 11 e 13 de dezembro de 2017, nós realizamos algumas atividades em companhia das crianças, brincadeiras de pular corda, corrida, pique; realização de peça de teatro; produção escrita, pintura e desenho. Em todos os casos o tema foi a infância nos contextos das personagens Pinóquio e Kiriku. Nossa disposição foi simples, ouvir as crianças e garantir que se expressassem.

Nossa perspectiva não foi entrevistar as crianças como uma aplicação de questionário. Mas, conversar com elas. Afinal, pesquisar não se baseia simplesmente em recolher dados ou acumular informações. Não podemos desconsiderar a relevância de encarar o "objeto" como sujeitos da pesquisa. Sem dúvida, queríamos enfatizar "as crianças como sujeitos culturais, relevando a autonomia da produção simbólica pelas crianças e sinalizando as características das práticas culturais das crianças e dos seus artefatos" (ARENHART, 2016, p. 12).

A peculiaridade que o trabalho de campo estabelece no contexto de pesquisadoras e pesquisadores que trabalham com as crianças não se pode perder de vista. Porque exige das pessoas adultas um processo de "desadultescimento". O que significa que não vamos pesquisar crianças; mas, com elas. Ao invés de fazer delas um objeto, o nosso intuito foi entrar em campo destacando o papel delas como sujeitos.

\begin{abstract}
Nessa perspectiva, em vez de pesquisar a criança, com intuito de melhor conhecê-la, o objetivo passa a ser pesquisar com a criança as experiências sociais e culturais que ela compartilha com outras pessoas de seu ambiente, colocando-a como parceira do adulto-pesquisador, na busca de uma permanente e mais profunda compreensão da experiência humana (JOBIM; CASTRO, 2008, p. 53).
\end{abstract}

Nos termos de William Corsaro, podemos falar em "adulto atípico", isto é, pessoa adulta que destoa da maioria. Corsaro saiu dos Estados Unidos da América para fazer

\footnotetext{
9 Importante mencionar que usamos o critério oficial de classificação cor/raça do Estado brasileiro cujo fiador é o Instituto Brasileiro de Geografia e Estatística (IBGE). De onde, a classificação possui cinco categorias: amarela, branca, indígena, parda e preta; as duas últimas: parda e preta ao serem somadas são denominadas de negra. Em conversa com professoras e pedido feito para a pedagoga da educação infantil e anos iniciais para briefing dos dados étnico-raciais das crianças ficou confirmada a ausência de crianças indígenas e amarelas.

${ }^{10}$ Filme estadunidense produzido por Walt Disney, direção de Norman Ferguson e estreia em 1940.

${ }^{11}$ Co-produção envolvendo vários países, tais como Luxemburgo, França e Senegal. Sob a direção de Michel Ocelot e lançamento em 1998.
} 
pesquisa na Itália sem dominar o idioma completamente. De modo que as crianças $\mathrm{O}$ objetivo estava explícito ser percebido pelas crianças como um adulto que podia se relacionar com elas sem ser uma pessoa que as ensinava, tutelava, avaliava ou atividades semelhantes que fariam da criança um tipo de prisioneira política de adultos. Tal como enfatizam Anete Abramowicz e Ana Moruzzi parafraseando o cineasta franco-suiço JeanLuc Godard: “As crianças são prisioneiras políticas, dizia Godard -, mas são prisioneiras de prisioneiros, porque os adultos, por maioria de razão, também são prisioneiros políticos (ABRAMOWICZ; MORUZZI, 2016, p. 32). As crianças ficam à mercê de pessoas adultas querendo "instrui-las", "formar o que supostamente estaria sem forma". Uma postura adultocêntrica que precisa ser confrontada para realizarmos uma pesquisa que leve em consideração o que as crianças pensam. Diante disso, tanto quanto possível, precisamos fazer uma espécie de abandono dos privilégios de ser adulto diante da criança.

Em certa medida, o que aqui denominamos de desadultescimento se baseia na noção de adulto atípico, isto é, uma pessoa adulta que não é professora, não tem funções pedagógicas ou quaisquer outras, seja psicóloga, gestora ou função disciplinar no contexto escolar. Daí, uma pessoa adulta que tem interesse em ouvir e saber o que as crianças pensam efetivamente, reconhecendo-as como sujeitos políticos e de conhecimento. Um tipo de adulto que observa o que elas fazem sem funcionar como agente de uma avaliação institucional. $\mathrm{O}$ que pode ser novo para algumas crianças, conhecer um adulto que não queria dar ordens e ensinar. Porém, ainda que nossas intenções fossem de escuta, não podemos desconsiderar o caráter assimétrico das relações entre pessoas adultas e crianças.

O pesquisador também precisa levar em conta a desigual relação de poder entre adultos e crianças, combinada com as também desiguais relações étnicas e de gênero, que muitas vezes levam as crianças a fornecerem as respostas que julgam serem as esperadas e não aquelas que refletem honestamente seu ponto de vista. Uma das formas de tentar superar essa distância, sugerida em outra parte do texto, é colocar-se como parceiro, falando sobre si próprio, procurando mostrar-se como pessoa (CAMPOS, 2008, p. 38).

Essa consciência foi fundamental para procurar criar condições mais favoráveis para uma escuta atenta, favorecendo a fala das crianças. No primeiro dia de encontro, nós começamos explicando os objetivos da pesquisa. Por sugestão da pedagoga responsável pela Educação Infantil e anos iniciais não reunimos o grupo focal. Ao invés disso, escalamos uma pessoa para ficar em cada sala. Na ocasião, conversamos sobre os dois filmes exibidos durante a semana. Nós explicamos os propósitos da pesquisa para estudantes, docentes e equipe pedagógica da Escola do Bairro, situando o propósito de 
conversar sobre o que se entende por infância a partir das aventuras de Pinóquio e de Kiriku. Em outras palavras, propomos que as crianças respondessem o que vocês achavam que significava a infância em duas circunstâncias diferentes nos contextos das vivências de Pinóquio e de Kiriku nos filmes assistidos.

Pesquisas com crianças demandam muitas conversas e autorizações, tanto da família como da própria criança assim como da escola. O que parte de uma compreensão da importância do estudo proposto. Tivemos então a apresentação da equipe de pesquisa às mães, aos pais ou adultos responsáveis, docentes e a equipe pedagógica da Escola, incluindo apresentação da pesquisa, objetivos, apresentação dos procedimentos (números de encontros, periodicidade e atividades previstas) que, a título de projeto piloto, foram nas datas: $30 / 11 / 2017 ; 05 / 12 / 2017 ; 11 / 12 / 2017 ; 13 / 12 / 2017$. Todas realizadas a partir das atividades prévias da exibição dos filmes Pinóquio, Kiriku e a Feiticeira. Daí, o quadro:

\begin{tabular}{|c|c|c|}
\hline Participantes & Atividade & Data \\
\hline $\begin{array}{l}\text { Todas as turmas do } 1^{\circ} \text { ao } \\
5^{\circ} \text { ano }\end{array}$ & $\begin{array}{l}\text { Etapa inicial, aproximação e } \\
\text { reconhecimento do campo. } \\
\text { Apresentação e dinâmica da } \\
\text { pesquisa. Colorir o desenho } \\
\text { dos rostos das personagens } \\
\text { Pinóquio e Kiriku }\end{array}$ & $30 / 11 / 2017$ \\
\hline Grupo Focal & $\begin{array}{l}\text { Dinâmica com brincadeiras do } \\
\text { Pinóquio e do Kiriku } \\
\text { Desenho do Kiriku e Pinóquio } \\
\text { Escrita coletiva. }\end{array}$ & $05 / 12 / 2017$ \\
\hline Grupo Focal & $\begin{array}{l}\text { Oficina teatral Kiriku e } \\
\text { Pinóquio, } \\
\text { Oficina de modelagem } \\
\text { (acessórios e roupas). }\end{array}$ & $11 / 12 / 2017$ \\
\hline Grupo focal & $\begin{array}{l}\text { Escrita das falas das peças } \\
\text { (coletivamente). Encenação da } \\
\text { peça. }\end{array}$ & $13 / 12 / 2017$ \\
\hline
\end{tabular}

O que foi pré-definido, um grupo focal com 20 crianças. Os quais seriam quatro alunos de cada ano, contemplando estudantes do $1^{\circ}$ ao $5^{\circ}$ anos do Ensino Fundamental, atentando a formação de um grupo diversificado em termos de gênero e cor/raça, chegando a seguinte formação:

\begin{tabular}{|l|l|l|}
\hline Grupo focal & Meninas & Meninos \\
\hline
\end{tabular}




\begin{tabular}{|c|c|c|}
\hline Crianças negras & 05 & 05 \\
\hline Crianças brancas & 05 & 05 \\
\hline
\end{tabular}

Mas, como já foi dito. Este quadro foi modificado, pois foram inseridas mais crianças, que no primeiro encontro participaram ativamente das atividades nas turmas, e os pais aprovaram a inclusão. Quando o grupo focal foi formado, ficamos com um total de 12 crianças negras e 13 crianças brancas. As crianças com deficiência foram dois meninos brancos, outro branco com altas habilidades, além de duas meninas (uma negra e outra branca), como ilustra a tabela abaixo:

\begin{tabular}{|c|c|c|}
\hline Grupo focal & Meninas & Meninos \\
\hline Cor branca & 06 & 07 \\
\hline Cor negra & 06 & 06 \\
\hline
\end{tabular}

Durante todos os encontros toda equipe de pesquisa fez cadernos de campo, fizemos gravações das conversas com as crianças, seus questionamentos, elaboração de escritas, decisões sobre a divisão dos grupos, construção de papéis para uma peça baseada nos filmes, além de fotografias e filmagens dos encontros. Neste texto vamos trazer alguns desenhos e pinturas dos rostos dos personagens Kiriku e Pinóquio.

\section{Assistindo e escolhendo entre Pinóquio e Kirikua}

As animações Pinóquio e Kiriku e a Feiticeira são o ponto de partida dos encontros com o grupo focal, na Escola da Baixada Fluminense no Rio de Janeiro. Essas animações foram uma forma de trazer questões sobre ser criança em lugares, tempos e sociedades diferentes. Rocha (2008), Cruz (2008), Sarmento (2011), Corsaro (2011) afirmam que, metodologicamente na escuta das crianças, mais do que perguntas e respostas, devemos criar estratégias de troca, de interação, como vários momentos de expressão e troca coletiva entre seus pares e os adultos pesquisadores.

Nas animações Pinóquio e Kiriku e a Feiticeira suas personagens principais nos trazem duas formas de pensar a infância e a autonomia da criança em contextos sociais diferentes. E nosso objetivo é ouvir como essas concepções de infância são partilhados 
pelas crianças, incluindo raça e etnia. Corsaro (2011) argumenta que, assim como os adultos, as crianças são participantes ativos na construção social da infância e na reprodução interpretativa de sua cultura compartilhada.

O filme de animação Pinóquio (1940), foi produzido pela Walt Disney Pictures e com direção de Norman Ferguson (1902-1957). O filme venceu o Oscar de melhor trilha sonora com a música "When you wish upon a star" composta por Leigh Harline e Ned Washington e, mais tarde, tema da Disney. O filme foi baseado na história contada pelo italiano Carlo Collodi (1826-1890). Collodi publicou originalmente num semanário infantil de 1881 a 1883.

O produtor de cinema estadunidense Walt Disney (1901-1965) fez uma opção estética e política para não ressaltar o lado agressivo e sarcástico da personagem de Carlo Collodi; afinal na trama original, Pinóquio mata o Grilo Falante e coloca Gepeto na prisão. Por isso, Disney preferiu fazer uma adaptação para que no filme de animação, Pinóquio parecesse ser uma inocente criança, que é enganada e comete erros como qualquer outra. $\mathrm{Na}$ sinopse comercial da animação a narrativa nos conduz a explorar as aventuras deste menino/boneco modificada; mas, mantendo o núcleo do conflito, o enredo-base em torno da busca do boneco de madeira tornar-se uma criança de verdade.

Gepeto é um carpinteiro solitário que, um dia, resolve fazer um boneco de madeira para lhe fazer companhia e lhe dá o nome de Pinóquio. Numa noite estrelada, uma fada azul dá vida a Pinóquio, começando então uma fantástica aventura que vai testar a coragem, a lealdade e a honestidade do boneco, virtudes que ele tem que aprender para se tornar um menino de verdade.

Ansioso para se tornar um menino de verdade, Pinóquio se mete em várias confusões, apesar dos constantes avisos de seu amigo Grilo Falante, até que precisa salvar Gepeto, que está preso dentro da barriga de uma baleia. O boneco tem uma particularidade: sempre que mente seu nariz cresce.

O filme de animação Kiriku e a Feiticeira (1998), foi produzido na França, Bélgica, Luxemburgo, Hungria e Senegal, com a direção de Michel Ocelot (1943). O diretor francês Ocelot escreve suas próprias histórias, desenha os personagens e cria seus universos gráficos. Um detalhe importante foi a infância do cineasta passada no país africano da Guiné, onde teve contato com a história tradicional.

Michel Ocelot segundo Yves Schaëffner ${ }^{12}$ (2000) passou por várias dificuldades na produção do filme e também recebeu várias críticas sobre a nudez do menino Kiriku, pois

\footnotetext{
12 SCHAËFFNER, Y. “Kirikou ou l’innocence récompensée”. Ciné-Bulles, Volume 18, numéro 4,
} 
a França vivia um momento da exacerbação da cultura da "moral e bons costumes". Mesmo com todas as críticas e dificuldades, a animação na França alcançou 1,3 milhões de espectadores no lançamento do filme. Youssou N'Dour, interprete e músico senegalês compôs a trilha sonora do filme e foi segundo o jornalista um investimento digno da Disney. Aqui um trecho da música, que expressa um pouco as características da personagem. "Kiriku não é grande [...] é o melhor de nós [...] Kiriku é pequeno [...]. E da feiticeira. Ele nos libertou".

A história é narra o nascimento de um menino minúsculo, cujo tamanho não alcança nem o joelho de um adulto na África Ocidental, região em que existiram grandes reinos Mandiga, Songhai e Wolof. O protagonista saiu do ventre de sua mãe, andando falando, fazendo tudo como uma criança já mais crescida e com destino à vista: enfrentar a poderosa feiticeira. Karabá, a feiticeira, descrita sempre como malvada e cruel, secou a fonte d'água da aldeia onde Kiriku vive, engoliu todos os homens que foram enfrentá-la e ainda pegou todo o ouro das mulheres. Para combater Karabá, Kiriku enfrenta muitos perigos e se aventura por lugares onde somente pessoas pequenas poderiam entrar. Assim, resumimos um pouco desta animação, que segundo o diretor, Michel Ocelot, numa entrevista para o Jornal $O \mathrm{Globo}^{13}$, afirma que, o que seduz o público é "a criança pequenina” e que muitas civilizações o fascinam, mas "a minha África soa verdadeira, é a minha infância: minha educação primária se deu em Conacri, na República da Guiné.”

Vale a pena repetir que essas duas animações foram exibidas às crianças da pesquisa pelas professoras da escola, com toda a turma do $1^{\circ}$ ao $5^{\circ}$ ano. Assim, poderíamos explorar com o grupo focal, a partir de um trabalho prévio feito pelas professoras em sala. As diferenças entre as personagens Pinóquio e Kiriku foram alvo de exame no artigo Pinóquio e Kiriku: infância(s) e educação nas filosofias de Kant e Ramose (NOGUERA, 2017).

Nossas reflexões teóricas identificam em Pinóquio uma ideia de infância passiva, onde a autonomia está ausente. Daí, “infância é o que se deve superar" (NOGUERA, 2017, p. 11). Enquanto Kiriku retrata a infância como uma dimensão da vida a ser preservada, porque justamente só ela é capaz de enfrentar os grandes desafios.

Como foi dito anteriormente, nosso primeiro encontro com o grupo focal não aconteceu como esperado, pois a coordenadora da escola tinha receio que as crianças menores ficassem caladas diante de um grupo de idades tão diferentes. Daí, pediu que

été 2000, p. 28-29. Acesso em 03 de Março de 2018 em http://id.erudit.org/iderudit/33595ac

13 Acesso em 03 de Março de 2018 https://oglobo.globo.com/cultura/filmes/animador-frances-conta-porque-decidiu-fazer-terceiro-kiriku-16812664 
fossemos de sala em sala nos apresentando e conversando com todas as turmas. Essa atitude protetora segundo Graue e Walsh (2003, p. 121) é compreensível por parte dos responsáveis por crianças pequenas e que nem sempre se sentem à vontade quando alguém de fora observa e interage com elas.

Algumas turmas estavam mais receptivas a ouvir e participar de uma conversa informal sobre as animações e em outras a passagem foi mais rápida, pois o tempo foi bem pequeno e as crianças tinham que ir para casa. Essa mudança de planejamento no trabalho de campo é segundo Graue e Walsh (2003, p. 127) uma improvisação que pressupõe um plano já direcionado, deve-se manter-se dentro dos parâmetros gerais do plano traçado. Como tínhamos traçado um plano para apenas as crianças do grupo focal, ampliamos para todas as turmas, pedindo mais cópias dos desenhos, agilizando nas apresentações e dividindo o grupo de pesquisadores por turmas.

A turma do $2^{\circ}$ ano estava arrumada com as carteiras em forma de "U" e uma coordenadora pedagógica também acompanhava essa turma. A professora estava sentada na sua mesa e nela continuou durante todo o tempo que interagimos com as crianças. Foram feitas brincadeiras para apresentação das crianças e nesta turma adultos misturaramse com estudantes e foi feita uma pergunta para cada criança, "qual personagem queriam pintar, Pinóquio ou Kiriku?”. A Escola providenciou os desenhos fotocopiados dos rostos Pinóquio e Kiriku retirados de páginas da internet.

No dia 30 de novembro de 2017, realizamos a primeira etapa. Por exemplo, no $2^{\circ}$ ano, a maioria da turma pegou mais desenhos do Pinóquio e logo começaram a colorir. Outras crianças decidiram pegar as duas personagens para colorir e no final, todos quiseram pintar as duas personagens Pinóquio e Kiriku. As crianças coloriam e informalmente fomos a cada criança anotando o porquê de ter escolhido tal personagem:

Menino 1, 7 anos: "Pinóquio é de madeira. Ele virou menino de verdade".

Menino 2, 8 anos: "Pinóquio é legal".

Menina 1, 7 anos: “a minha família é toda negra. Meu pai é Branco, por isso escolhi o Kiriku".

Menina 2, 7 anos: "Pinóquio é legal”.

Menina 3, 7 anos: "Pinóquio é legal, aventureiro".

Menina 4, 9 anos: "Kiriku, porque ele salvou a aldeia dele e ele disse que não era pra subir na árvore. Ele é inteligente, corajoso".

Menino 3, 8 anos: "Pinóquio, ele salvou o pai da baleia". 
Menino 4, 8 anos: "Pinóquio porque ele salvou o pai da baleia".

Menina 5, 7 anos: "Pinóquio porque ele é legal e corajoso. Não escolhi o Kiriku, porque estou acostumada com o Pinóquio".

Menina 3, 7 anos: "Eu estava em dúvida, aí peguei os dois. Os dois são meninos. Pinóquio é um boneco. Kiriku é um menino”.

Menino 5, 8 anos: "Pinóquio, porque ele tem um final feliz, porque ele é de madeira e vira um menino".

Menino 6, 7 anos: "Kiriku, porque ele salvou a aldeia. Eu gosto mais dele. Eu assisti em casa. Eu assisti do Pinóquio em casa, na tevê, não gostei do Pinóquio. Kiriku é mais rápido, mais ágil”.

Menina 3, 7 anos: "Pinóquio vira criança, o Kiriku vira homem. Prefiro ser criança".

Menina 6, 7anos: "Pinóquio, porque ele é engraçado, criança, meio atrapalhado. Kiriku eu gostei, ele virou um homem rápido. Não é bom. Porque é chato ser adulto. Tem que pagar conta, ir ao mercado. Minha mãe trabalha aqui na escola, no escritório".

Aqui não vamos nos debruçar longamente sobre as frases dessas crianças acima transcritas. Mas, percebemos que em algumas falas com a valorização da infância, Kiriku é criticado por virar adulto no final. Enquanto Pinóquio é celebrado por se transformar em criança. A condição de criança foi bastante valorizada nos comentários textos.

Após colorirem foi proposto, que escrevessem uma frase para cada personagem, atrás do desenho. Essa escrita é mais uma forma de ouvir a voz das crianças, pois segundo Sarmento (2011, p. 28), ouvir a vOz das crianças não significa necessariamente escutar, mas utilizar outros canais ou meios de comunicação que se colocam fora da expressão verbal, como o desenho e a escrita. Vale destacar que a menina 1 é negra e frisou que, apesar do pai ser branco, todo o restante da família é negra e essa foi a razão de escolher o personagem Kiriku.

A coordenadora pedagógica que estava acompanhando a turma chamava a atenção do menino 1, várias vezes e veio justificar o porquê dele falar muito e interromper colegas: ele tinha altas habilidades ${ }^{14}$. Outro aluno especial, que não falava e comunicava-se por gestos ficou mais perto da professora e só interagiu quando as crianças foram liberadas para brincar pela sala. Algumas dessas crianças especiais que participaram desse primeiro encontro foram incluídas no grupo focal, por entendermos que existem múltiplas infâncias e Rocha (2008, p.44) afirma que, ainda temos muito que aprender e conhecer sobre elas em diferentes contextos.

14 Por alta habilidades se deve entender a "capacidade" de raciocinar mais rápido do que a maioria em determinadas áreas. O que já foi denominado de superdotação. 
As crianças leram em voz alta as frases que escreveram, apenas porque a coordenadora pediu que assim fizessem, mas nem todos prestaram atenção nesse momento. Rocha (2008, p. 49) recomenda nas pesquisas com crianças, ir além da escrita e da oralidade, há uma necessidade de cruzar falas, com desenhos, fotografias, em vez de privilegiar perguntas diretas, pois isso amplia uma relativização do ponto de vista do adulto. E é o que faremos a seguir com os desenhos feitos pelas crianças.

Nós preferimos não fazer perguntas diretas, de modo que induzíssemos as crianças a responderem o que presumiriam que desejamos ouvir. Por essa razão, concentramos num assunto mais geral e deixamos de lado, intencionalmente, as indagações sobre pertencimento racial e cultural das personagens e o porquê de não termos sugerido um filme com uma personagem infantil feminina protagonista.

\section{Os desenhos}

$\mathrm{Na}$ tabela, apresentamos algumas características ressaltadas pelas crianças para cada personagem:

\begin{tabular}{|l|l|}
\hline \multicolumn{1}{|c|}{ PINÓQUIO } & \multicolumn{1}{c|}{ KIRIKU } \\
\hline Legal & Rápido \\
\hline Aventureiro & Ágil \\
\hline Corajoso & Menino \\
\hline Menino & Inteligente \\
\hline Boneco de madeira & Corajoso \\
\hline Engraçado & Negro \\
\hline Criança & Valente \\
\hline Mentiroso & \\
\hline
\end{tabular}

Aqui as crianças pintaram representando mais ou menos as cores das personagens vistas nas animações e interagiam entre seus pares para escolherem as cores e trocarem os lápis. Segundo Martins Filho (2010, p. 24), o desenho é compreendido como atividade de criação e expressão humana. Nesse sentido, com a especificidade do desenho, aparece a consideração de quatro aspectos que o descrevem: o autor (a criança que o desenha), o próprio desenho em si, a fala do autor que o produz e o contexto em que ele é produzido. 


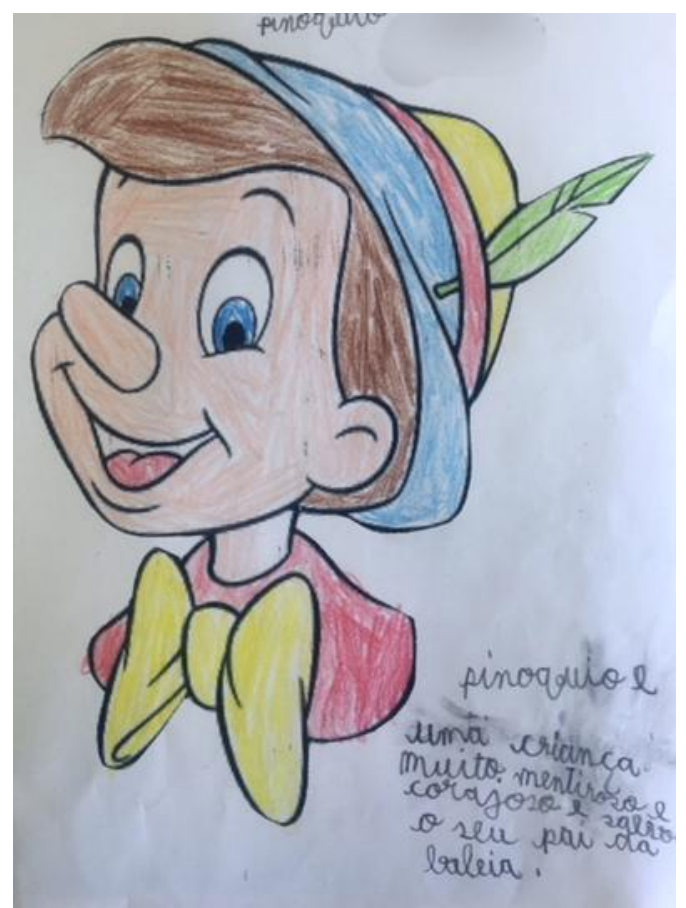

Essa criança do $2^{\circ}$ ano escolheu Pinóquio, porque o achou corajoso e o principal é que salvou seu pai no fim da animação. O final foi feliz.

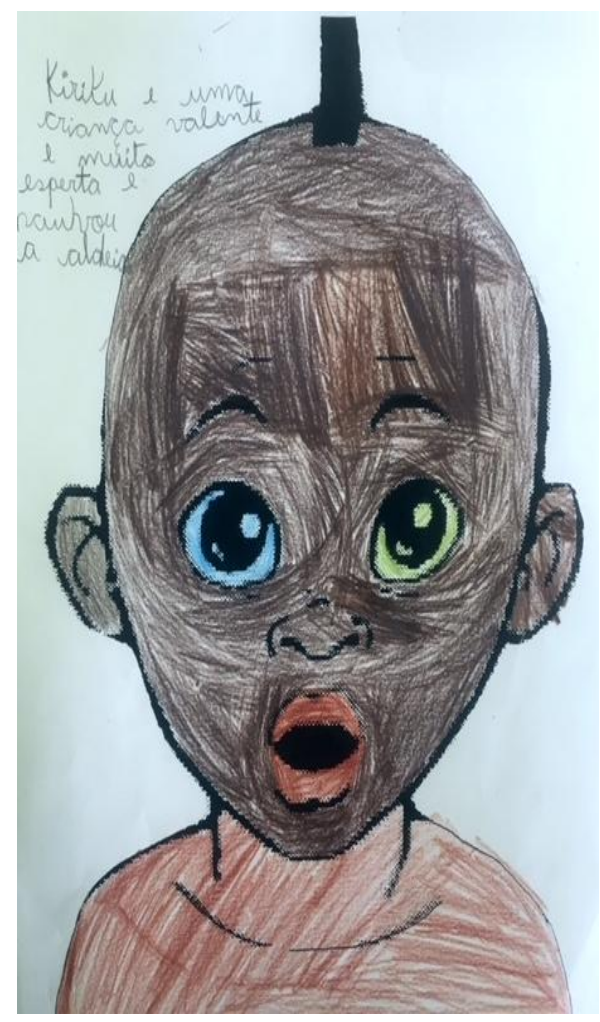


A criança é do $2^{\circ}$ ano e utilizou as cores marrom e preto, pintando a boca do Kiriku de marrom e não vermelho. A importância de uma criança salvar uma aldeia aparece no texto. Importante notar que se trata de uma menina negra.

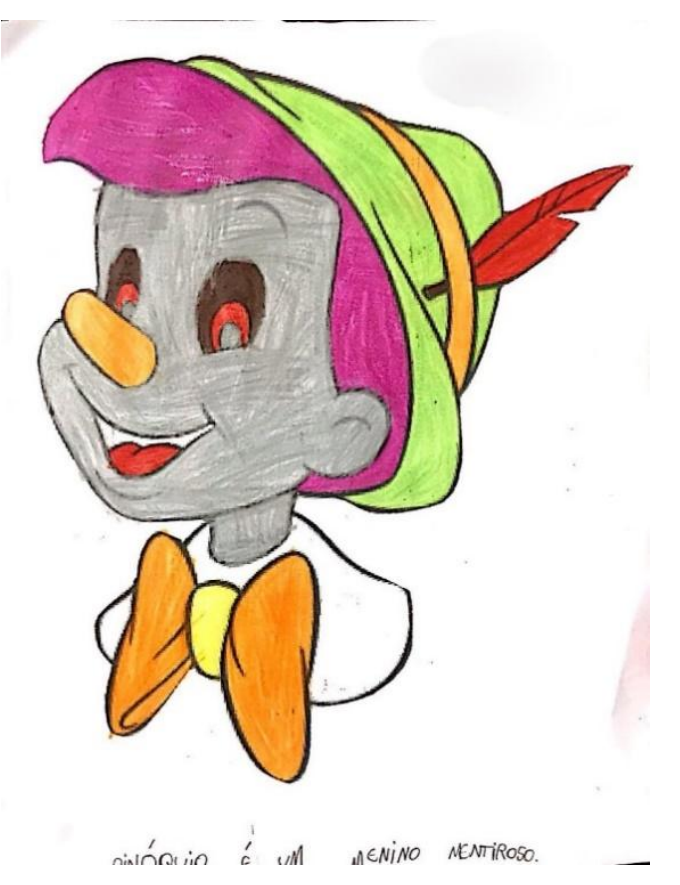

Nessa etapa, antes do grupo focal encontramos perspectivas bem diversas. A criança pintou o Pinóquio com a cor preta. A cor marca o fenótipo negro e a criança reforça dizendo que estava pintando como o Kiriku, pois gostou mais dessa personagem. $\mathrm{Na}$ escolha das personagens, as crianças escolheram mais desenhos do Pinóquio do que do Kiriku. Na fala da criança de duas crianças aprece o conflito da escolha da personagem e também a animação que é mais conhecida pelo grupo. Vale a pena repetir os trechos:

Menina 3, 7 anos: "Eu estava em dúvida, aí peguei os dois. Os dois são meninos. Pinóquio é um boneco. Kiriku é um menino".

Menina 5, 7 anos: "Pinóquio porque ele é legal e corajoso. Não escolhi o Kiriku, porque estou acostumada com o Pinóquio".

No primeiro caso, ser-criança, ser um menino é uma "atribuição" de Kiriku. Pinóquio é descrito como um boneco, não-humano. Mas, outra criança coloca a familiaridade como quesito importante.

De acordo com Sarmento (2011, p. 52), a criança verbaliza suas escolhas tanto nos desenhos, quanto no que diz respeito aos motivos dessa escolha, que pode parecer muitas vezes paradoxal e ininteligível para o adulto. $\mathrm{Na}$ tabela apresentamos as escolhas das 
personagens pelas crianças, na ocasião, as crianças do $5^{\circ}$ ano não participaram dessa enquete.

\begin{tabular}{|l|c|c|}
\hline \multicolumn{1}{|c|}{ Personagens } & Pinóquio & Kiriku \\
\hline $\begin{array}{l}1^{\circ} \text { ano (turma com } \\
25 \text { estudantes) }\end{array}$ & 17 & 8 \\
\hline $2^{\circ}$ ano (turma com & & \\
$19 \quad$ alunos \\
estudantes)
\end{tabular}

A partir do segundo encontro, nós ficamos exclusivamente com o grupo focal. $\mathrm{O}$ que facilitou a continuidade das atividades. Daí, decidimos desenhar e usar frases em cada No desenho abaixo, a criança é do terceiro ano e compara Kiriku e Pinóquio.

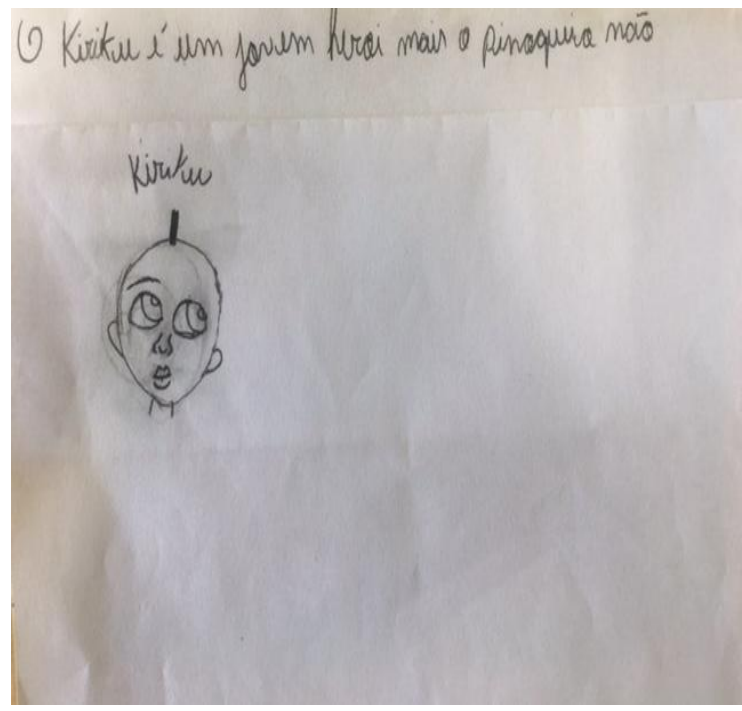

$\mathrm{Na}$ frase escrita pela criança, Kiriku é definido como herói; Pinóquio, não. Seu desenho segue a reprodução do que foi pintado no primeiro encontro. Pinóquio não aparece no desenho. O que observamos que se repete em outros desenhos, uma valorização de Kiriku como um tipo de criança louvável em detrimento do Pinóquio visto como "mentiroso". Sarmento (2011, p. 49) afirma que, há um diálogo entre os pares, principalmente quando o desenho é realizado na escola. Há que perceber um autor coletivo nas formas, nas escolhas das cores. Para o autor o que ela procura nessa relação com seus pares, é a procura de formas comuns comparáveis. Se seu desenho é parecido com o dos 
pares, então todos entenderão o que estou desenhando, até os adultos. Essas duas crianças estavam próximas no grupo focal e trocavam informações e dialogavam sobre as
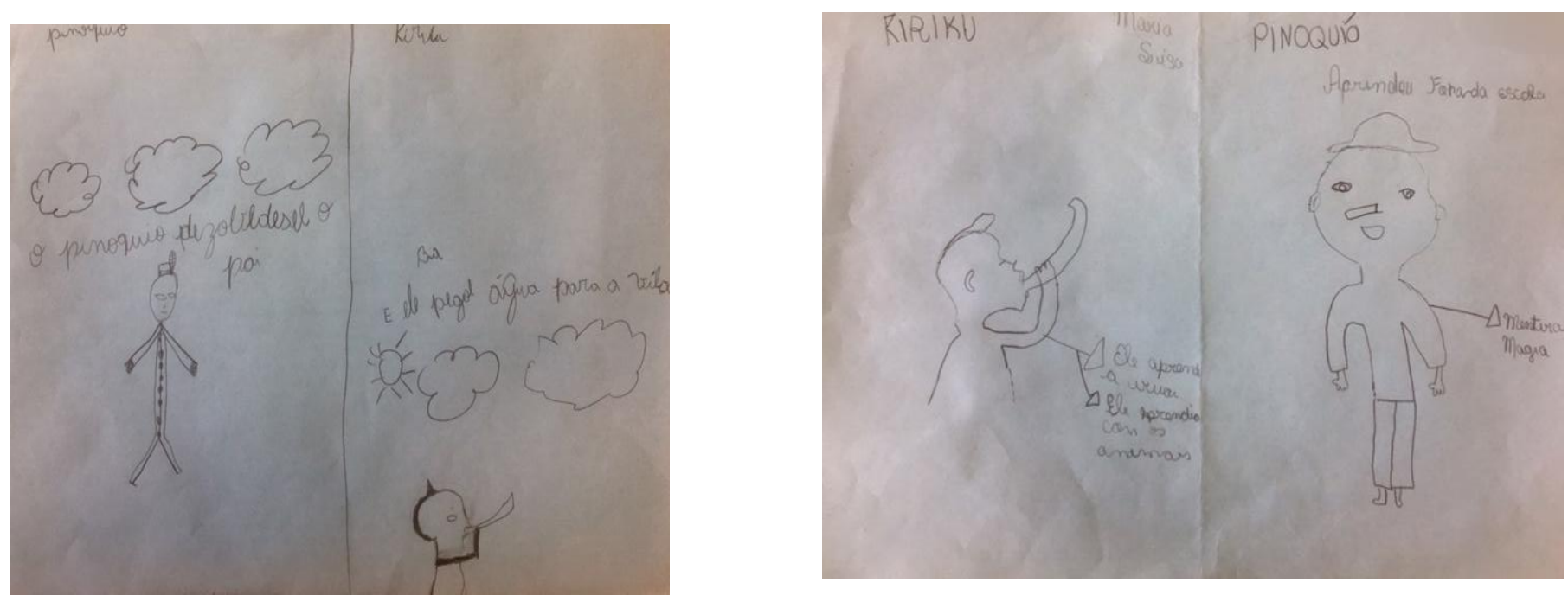

animações.

Nos desenhos percebemos uma predominância da atribuição da qualidade de heroísmo para Kiriku; enquanto Pinóquio assume os papéis de criança - o que está longe de ser negativo - e "mentiroso". 


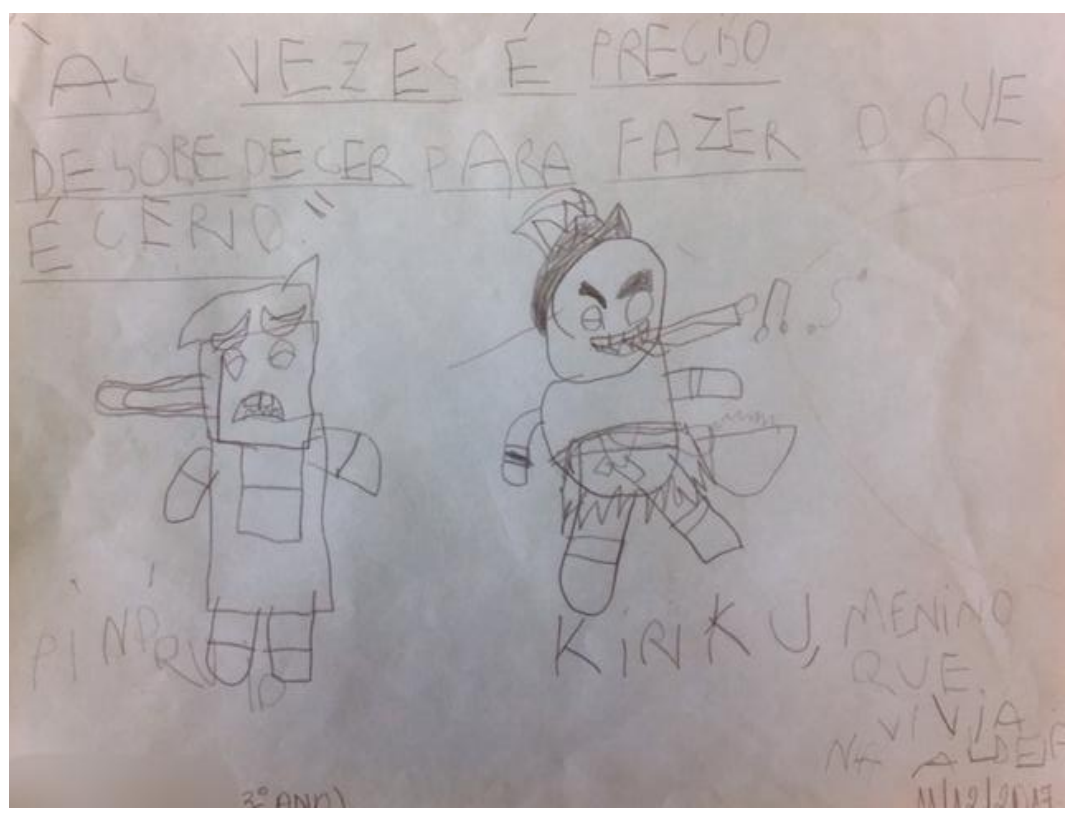

No desenho acima, frases como é preciso desobedecer remetem ao personagem Kiriku. Afinal, o menino Kiriku enfrentou a opinião de todas as pessoas da aldeia foi capaz de fazer o improvável, vencer uma batalha que nenhum adulto conseguiu êxito. Neste desenho abaixo, aparece a frase, "ele nasceu sabendo"; uma explícita referência a Kiriku.

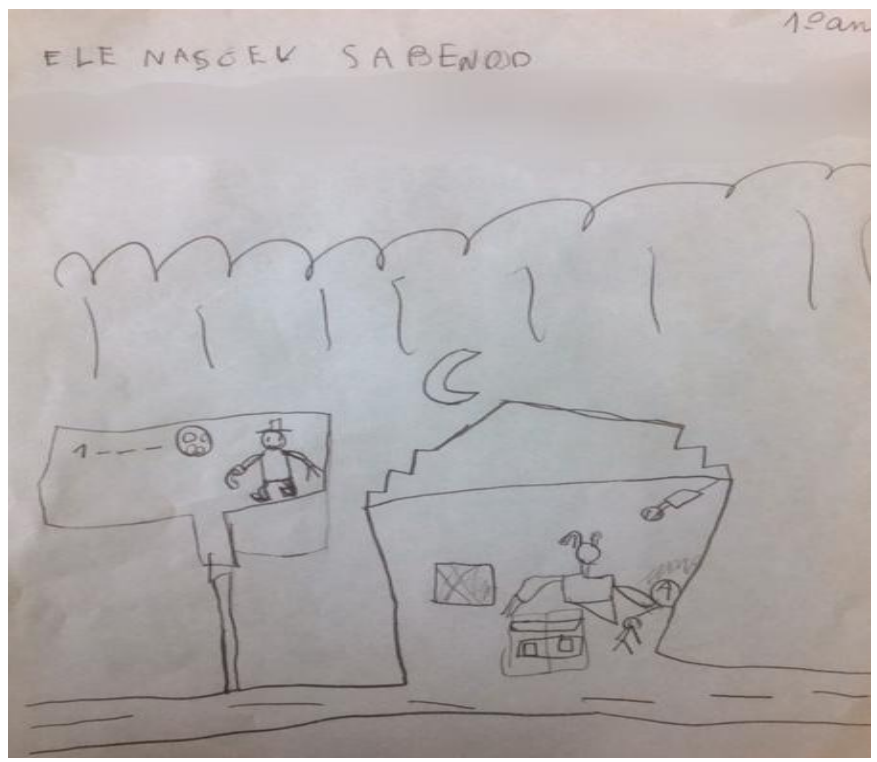

(In) conclusões parciais 
A nossa hipótese inicial foi confirmada. Durante as escolhas feitas em sala para pintar os rostos das personagens dos filmes, encontramos uma predominância por Pinóquio. Mas, com o início da investigação com o grupo focal, os desenhos e frases contrastaram bastante com as falas da maioria da turma. $O$ grupo focal que vivenciou efetivamente as experiências de bate papo, brincadeiras, construção de peça teatral, escritas individuais e coletivas definiu que a personagem Kiriku "representava" uma vivência da infância mais autônoma do que Pinóquio.

A partir de algumas questões que temos procurado investigar, tais como a percepção que as crianças têm sobre as relações étnico-raciais e de gênero. É importante destacar que colocamos em discussão duas perspectivas de infância. Nos dois casos as personagens eram meninos. Porém, sendo um negro e o outro branco. Durante a narrativa, o menino negro seria um tipo de representante de um sistema cultural que contribuiu para pensarmos uma maneira de vivenciar a infância de matriz africana. Enquanto Pinóquio, um menino branco vivenciando num contexto europeu uma ideia de infância bem diferente daquela apresentada por Kiriku. Nenhuma criança se interessou por formular essa diferença baseada em critérios raciais ou culturais. Não enfatizaram o caráter branco do personagem Pinóquio, nem destacaram o contexto geográfico. Não tivemos desenhos que tivessem elementos visuais que remetessem à África ou à Europa. Pelo radar das crianças, algumas questões não foram destacadas. Vale lembrar que nosso intuito não foi "fabricar" respostas. Por isso, evitamos criar condições para que as crianças abordassem coisas que gostaríamos que elas levassem em conta. Porque o objetivo era um breve inventário geral dos elementos que mais chamaram atenção delas nos dois filmes. Gênero apareceu apenas numa frase da primeira etapa antes da constituição do grupo focal; uma menina disse: "Eu estava em dúvida, aí peguei os dois. Os dois são meninos. Pinóquio é um boneco. Kiriku é um menino". A fala dela pode ser dividida em três partes: primeiro enunciado, a dúvida; em seguida: ela enfatiza que são dois meninos. Por fim, diz que escolheu o "menino" ao invés do boneco. A nosso ver, a palavra menino aparece como um autêntico significante flutuante que aparece como sendo uma descrição da condição de gênero, menino enquanto uma criança do sexo masculino. Em seguida, "menino" aparece como um contraponto ao não-humano, ao boneco; menino como sinônimo de criança. Fora essa alusão ao dado de que os dois personagens são do sexo masculino, não encontramos mais conjecturas sobre relações de gênero a partir do filme. $\mathrm{Na}$ fase dos grupos focais não tivemos alusões a esse debate. Na primeira etapa de apresentação da pesquisa, o quesito cor foi mencionado 
sempre em relação ao personagem Kiriku. No momento em que as crianças foram pintar as personagens.

A equipe não criou expectativas. Nós tínhamos uma indagação que não foi colocada nos encontros, a cultura africana presente no filme Kiriku e a Feiticeira é um elemento importante para entendermos a noção de infância autônoma e protagonista? Por outro lado, a cultura ocidental na qual o filme Pinóquio está inserido é o que faz com que a infância seja desacreditada? Ora, um elemento interessante retratado foi que a desobediência de Kiriku não tinha o sentido de desvirtuá-lo, tampouco significava uma "mentira". Num dos desenhos de uma criança do grupo focal encontramos a frase, "às vezes é preciso desobedecer para fazer o que é certo". Ora, isso em referência a atitude de Kiriku. Afinal, o personagem da história africana enfrentou pessoas adultas e trouxe alternativas que elas não tinham, numa interação dialógica com o mundo adulto; mas, na qual a criança se constitui como o sujeito agente da transformação. No caso do Pinóquio, ainda que ele salve o pai no final da história, o menino é constantemente convidado a amadurecer e obedecer pessoas adultas.

O que no grupo focal produziu uma nítida conclusão através dos desenhos, Pinóquio representava uma experiência da infância mais limitada e com menos autonomia. Sem dúvida, as representações gráficas feitas pelas crianças acompanhadas de frases retratam Kiriku positivamente. Kiriku foi a infância celebrada em que questionar e desobedecer são atitudes importantes que levam a bons caminhos, estimulando as crianças e se configurando como representação de uma vivência interessante. Enquanto, Pinóquio foi situado como um tipo de experiência da infância que não se deve imitar.

\section{Referências}

ABRAMOWICZ, Anete; MORUZZI, Andrea Braga. Infância na contemporaneidade: questões para os estudos sociológicos da infância. Crítica Educativa (Sorocaba/SP), v. 2, n. 2, p. 25-37, jul./dez. 2016, pp. 25-37.

BACKES, Dirce; COLOMÉ, Juliana Silveira; ERDMANN, Rolf; LUNARDI, Valéria. Grupo focal como técnica de coleta e análise de dados em pesquisas qualitativas. O mundo da saúde, São Paulo, 2011, pp. 438-442.

BARROS, Eurico. Pinóquio do Walt Disney faz 70 anos sem sentir a idade. Disponível em: $<$ https://www.dn.pt/artes/cinema/interior/pinoquio-de-walt-disney-faz-70-anos-semsentir-a-idade--1488691.html > Acesso em 17 de março de 2018. 
BLOG DEVIR-NOMÂDE. Viagens et Filosofia. Disponível em $<$ http://devirnomadeviagem.blogspot.com.br/2012/10/pinocchio.html?m=1> Acesso em 17 de março de 2018.

BLOG LUIZ NASSIF ONLINE. Carlo Collodi, o criador de Pinóquio. Disponível em: $<$ https://jornalggn.com.br/blog/luisnassif/carlo-collodi-o-criador-de-pinoquio > Acesso em 17 de março de 2018.

CORSARO, William A. Sociologia da infância. Porto Alegre: Artmed, 2011.

CRUZ, Silvia Helena Vieira. A criança fala, a escuta de crianças em pesquisas. São Paulo: Cortez, 2008.

FESTIVAL INTERNACIONAL DE CINEMA INFANTIL. Disponível em: $<$ http://festivaldecinemainfantil.com.br/2012/static/content/pdf/278.pdf > Acesso em 17 de março de 2018.

GIANINNI. Alessandro. Animador Francês conta porque decidiu fazer o terceiro "Kiriku" Michel Ocelot defende o cinema artesanal em respostas as producōes industriais da Disney e Pixar. Disponível em: <https://oglobo.globo.com/cultura/filmes/animador-frances-conta-por-que-decidiufazer-terceiro-kiriku-16812664 > Acesso em 17 de março de 2018.

GUIRRA, Luiz. O Cinema de Michel Ocelot exibe no CCBB dois fins de semanas com filmes de animação. Disponível em: < https://recantoadormecido.com.br/2016/10/17/o-cinema-demichel-ocelot-exibe-no-ccbb-dois-fins-de-semanas-com-filmes-de-animacao-do-diretor/> Acesso em 17 de março de 2018.

GRAUE, M. Elizabeth; WALSH, Daniel. Investigação Etnográfica com crianças: teorias, métodos e ética. Lisboa: Fundação Calouste Gulbekian, 2003.

MARTINS FILHO, Altino José; BARBOSA, Maria Carmem. Metodologias de Pesquisa com Crianças. Revista Reflexão e Ação, Santa Cruz do Sul, v.18, n2, p.08-28, jul. /dez. 2010.

NOGUERA, Renato. Pinóquio e Kiriku: infâncias e educação nas filosofias de Kant e Ramose. Revista Aú, Ano 02, 2017a, pp.5-18.

"Kiriku: heterônimo da infância como experiência e da experiência da infância. Anais do Congresso de Estudos da Infância: Diálogos Contemporâneos, Rio de Janeiro: Uerj, 2017b, pp. 363-370.

ROCHA, Eloísa Acires Candal. Por que ouvir as crianças? Algumas questões para um debate científico multidisciplinar. In: CRUZ, Silvia Helena Vieira. A criança fala, a escuta de crianças em pesquisas. São Paulo: Cortez, 2008.

SARAMAGO, Silvia Sara. Metodologias de pesquisa empírica com crianças. Sociologia, Problemas e Práticas, n. 35, 2001, pp. 9-29.

SARMENTO, Manuel Jacinto. Conhecer a infância: os desenhos das crianças como produções simbólicas. In: MARTINS FILHO, Altino José; PRADO, Patrícia Dias (Orgs.). Das pesquisas com crianças à complexidade da infância. São Paulo: Autores Associados, 2011. 
SCHAËFFNER, Y. Kirikou ou l'innocence récompensée. Ciné-Bulles, V. 18, n. 4, p. 28-29, 2000. Disponível em: < http://id.erudit.org/iderudit/33595ac > Acesso em 17 de março de 2018. 